\title{
EXPLOSION SEISMIC OBSERVATION OF REFLECTED WAVES FROM THE MOHOROVICIC DISCONTINUITY AND CRUSTAL STRUCTURE IN WESTERN KANTO DISTRICT
}

\author{
Yoshiyuki Kaneda, ${ }^{* 11}$ Noritake Nishide, ${ }^{* 21}$ Yoshimi SASAKI, ${ }^{* *}$ \\ Shuzo Asano, , Toshikatsu Yoshri, ${ }^{*}$ Yoichiro IChInose, ${ }^{*}$ \\ and Mamoru SAKA* \\ * Earthquake Research Institute, University of Tokyo, Tokyo, Japan \\ **Faculty of Education, Gifu University, Gifu, Japan
}

(Received July 13, 1979)

In 1977 and 1978, three explosions of $500 \mathrm{~kg}$ were carried out in a reclaimed land, Yumenoshima, in the northern part of Tokyo Bay, and a quarry blast was made at Inabu in the northeastern part of Aichi Prefecture, Central Japan. Seismic waves generated by these four explosions were observed for an investigation of crustal structure in the western Kanto district. A distinct late arrival was recorded in seismograms from Yumenoshima explosions. Mainly from the travel time analysis, this arrival is identified with the reflected wave from the Mohorovicic discontinuity. Combining travel times of the reflected wave with those of first arrivals, a model of crustal structure in the western Kanto district is derived. It is found that the crust thickens toward the Fossa Magna and its thickness is about 38 to $45 \mathrm{~km}$.

\section{Introduction}

Investigations of the crust and upper mantle structure by means of the explosion seismic method have been carried out since 1950 mainly by the Research Group for Explosion Seismology in Japan. Distinct reflections from the Mohorovicic discontinuity (the Moho), however, have hardly ever been observed, though they have usually been observed in the typical continental regions like Europe. The crustal structure beneath the western part of Japan has been considered to be simple. Even in KurayoshiHanabusa profile in this area, however, reflected waves from the Moho were not very clear, while clear ones were observed from the Conrad discontinuity (Yoshir et al., 1973).

To observe reflected waves from the Moho effectively with a small

Present address: ${ }^{11}$ Japan National Oil Corporation, Tokyo, Japan, ${ }^{2} J a p a n$ Meteorological Agency, Tokyo, Japan. 
number of stations, observation for such reflected waves around the critical distance is most useful, since the maximum amplitude is then expected from a theoretical consideration. For this purpose, seismic waves generated by the sixth through eighth Yumenoshima explosions (charge size of each explosion: $500 \mathrm{~kg}$ ) and the Inabu quarry blast (charge size: 7 tons) were observed near the critical distance inferred from the existing information on the crustal structure of the area concerned. The Yumenoshima explosions were conducted by Shutoken Kibankozo Kenkyu Group (Research Group for Basement Structure in Tokyo Metropolitan Area-abbreviated as RGBS in this paper) to study the structure of the basement in the Tokyo Metropolitan area. The sixth, seventh and eighth Yumenoshima explosions were carried out on November 6, 1977, on March 19 and October 26, 1978, respectively. The Inabu quarry blast was made on February 18, 1978. The observation was successful in recording distinct later arrivals from the Yumenoshima explosions.

In this paper, results of analysis of these distinct later arrivals and the crustal structure in the western Kanto district derived from travel time data in these experiments are presented.

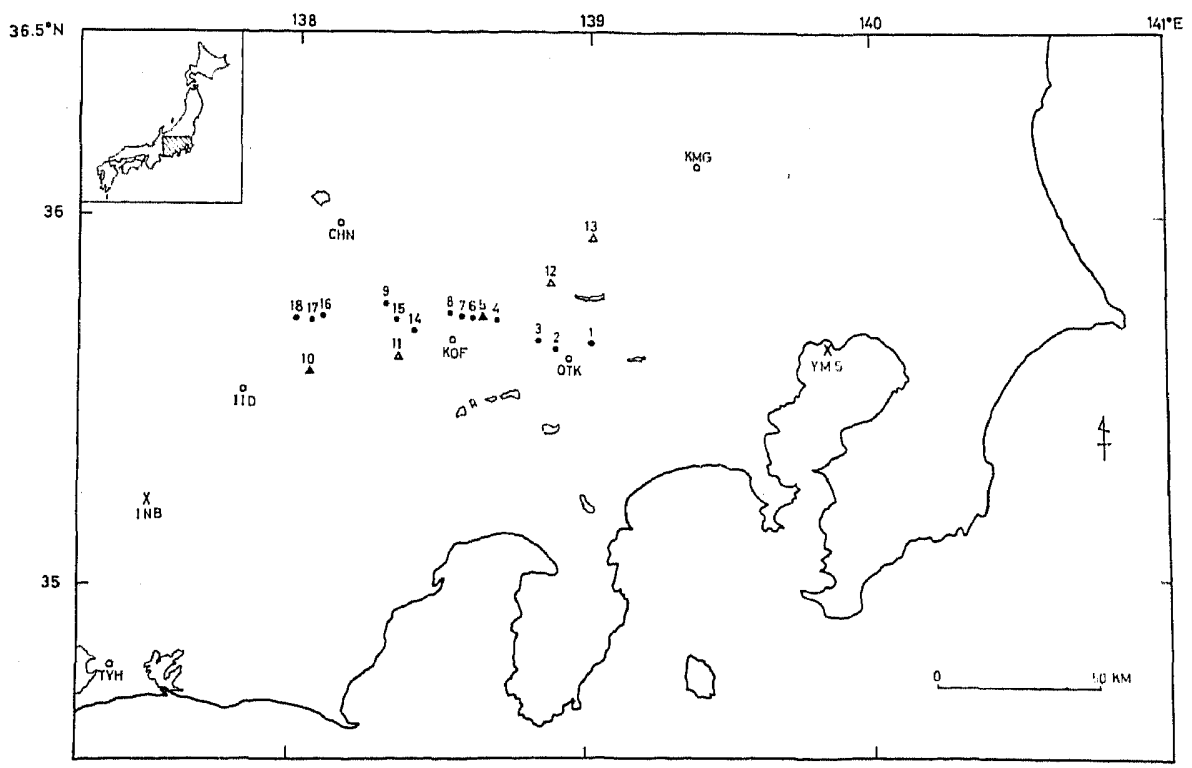

Fig. 1. Locations of shot and observation points. Cross mark, shot point, YMS (Yumenoshima), INB (Inabu); solid circle, observation point in Yumenoshima explosions; open triangle, observation point in the Inabu quarry blast; solid triangle, observation point in Yumenoshima explosions and the Inabu quarry blast; open circle, city, KMG (Kumagaya), OTK (Otsuki), KOF (Kofu), CHN (Chino), IID (Iida), TYH (Toyohashi). 


\section{Observation}

Locations of shot points and observation stations are shown in Fig. 1 and listed in Table 1. The station No. 10 is one of the satellite stations of the seismological network of Nagoya University. Observations at temporary stations were made with hand-made FM cassette magnetic tape recorders operated by batteries.

Table 1. Locations of shot and observation points, distance and observers.

\begin{tabular}{|c|c|c|c|c|c|c|}
\hline $\begin{array}{l}\text { Station } \\
\text { number }\end{array}$ & $\begin{array}{l}\text { Observation } \\
\text { point }\end{array}$ & $\begin{array}{l}\text { Latitude } \\
\qquad(\mathrm{N})\end{array}$ & $\begin{array}{l}\text { Longitude } \\
\text { (E) }\end{array}$ & $\begin{array}{l}\text { Height } \\
\text { (m) }\end{array}$ & $\begin{array}{l}\text { Distance } \\
(\mathrm{km})\end{array}$ & Observers \\
\hline YMS & Yumenoshima & $35^{\circ} 36^{\prime} 57.8^{\prime \prime}$ & $139^{\circ} 50^{\prime} 19.7^{\prime \prime}$ & 0 & & \\
\hline 1 & Asakawa & $\begin{array}{lll}35 & 39 & 07.4\end{array}$ & 1390029.0 & 600 & 75.34 & N. Nishide* \\
\hline 2 & Kuwanishi & $\begin{array}{lll}35 & 38 & 11.8\end{array}$ & $13853 \quad 11.5$ & 750 & 86.27 & S. Asano* \\
\hline 3 & $\begin{array}{l}\text { Tenmokuzan A } \\
\text { Tenmokuzan } \mathrm{B}\end{array}$ & $\begin{array}{lll}35 & 39 & 12.0 \\
35 & 39 & 30.6\end{array}$ & $\begin{array}{lll}138 & 49 & 13.8 \\
138 & 48 & 42.2\end{array}$ & $\begin{array}{l}1,000 \\
1,050\end{array}$ & $\begin{array}{l}92.30 \\
93.12\end{array}$ & $\begin{array}{l}\text { M. Saka* } \\
\text { Y. Kaneda* }\end{array}$ \\
\hline 4 & Mizuguchi & 354242.0 & 1384124.0 & 440 & 104.53 & Y. Kaneda* \\
\hline 5 & Hotokezawa & 354308.4 & 1383639.0 & 640 & 108.73 & S. Asano* \\
\hline 6 & Toichi & 354315.6 & 1383633.6 & 1,050 & 111.93 & Y. Sasaki** \\
\hline 7 & Touiwa & 354326.9 & 1383431.1 & 750 & 114.99 & Y. Sasaki** \\
\hline 8 & Urushido & 354355.8 & 1383146.8 & 560 & 119.18 & Y. Seto** \\
\hline 9 & Otakegawa & 354544.1 & $13818 \quad 47.0$ & 780 & 139.01 & Y. Endo** \\
\hline 10 & Oshika & 353446.8 & 1380255.5 & 810 & 162.22 & Nagoya Univ \\
\hline 14 & Amarizawa & $3541 \quad 00.4$ & $138 \quad 2500.5$ & 690 & 128.96 & N. Nishide* \\
\hline 15 & Gozaishi & $\begin{array}{lll}35 & 43 & 11.7\end{array}$ & $13821 \quad 16.7$ & 1,070 & 134.84 & X. Kaneda* \\
\hline 16 & Komagane 1 & $3543 \quad 14.6$ & $\begin{array}{lll}138 & 05 & 39.5\end{array}$ & 970 & 158.36 & $\begin{array}{l}\text { Y. Sasaki** } \\
\text { T. Nomura** }\end{array}$ \\
\hline 17 & Komagane 2 & $35 \quad 4258.4$ & 1380321.9 & 1,111 & 161.76 & $\begin{array}{l}\text { T. Souma** } \\
\text { S. Taguchi** }\end{array}$ \\
\hline 18 & Komagane 3 & $\begin{array}{lll}35 & 4309.6\end{array}$ & $13800 \quad 11.2$ & 720 & 166.57 & $\begin{array}{l}\text { F. Kachi** } \\
\text { R. Kanou** }\end{array}$ \\
\hline INB & Inabu & 351333.9 & 1373123.8 & 620 & & \\
\hline 10 & Oshika & 353446.8 & 1380255.5 & 810 & 61.76 & Nagoya Univ \\
\hline 11 & Yashazin & 353709.0 & 1382127.0 & 900 & 87.39 & Y. Kaneda* \\
\hline 5 & Hotokezawa & $\begin{array}{lll}35 & 43 & 08.4\end{array}$ & 1383639.0 & 640 & 115.46 & $\begin{array}{l}\text { M. Saka* } \\
\text { N. Nishide* }\end{array}$ \\
\hline 12 & Ichinose & 354833.9 & $\begin{array}{lll}138 & 51 \quad 37.1\end{array}$ & 1,100 & 137.43 & Y. Ichinose* \\
\hline 13 & Shiroku & 355629.2 & 1390000.8 & 460 & 155.57 & T. Yoshii* \\
\hline
\end{tabular}

The sixth Yumenoshima explosion The seventh Yumenoshima explosion The eighth Yumenoshima explosion Inabu quarry blast

\section{Shot time}

$\begin{array}{llll}03 & 04^{\mathrm{m}} & 59.48 & \\ 03 & 01 & 59.210 & \text { November } 6,1977 \\ 02 & 01 & 59.106 & \text { October } 26,1978 \\ 10 & 00 & 24.522 & \text { February 18, 1978 }\end{array}$

The shot time is also given for the sixth through the eighth Yumenoshima explosions.

* Earthquake Research Institute, University of Tokyo, Tokyo.

** Faculty of Education, Gifu University, Gifu. 
514 Y. Kaneda, N. Nishide, Y. SAsaki, S. Asano, T. Yoshi, Y. IChinose, and M. SaKa

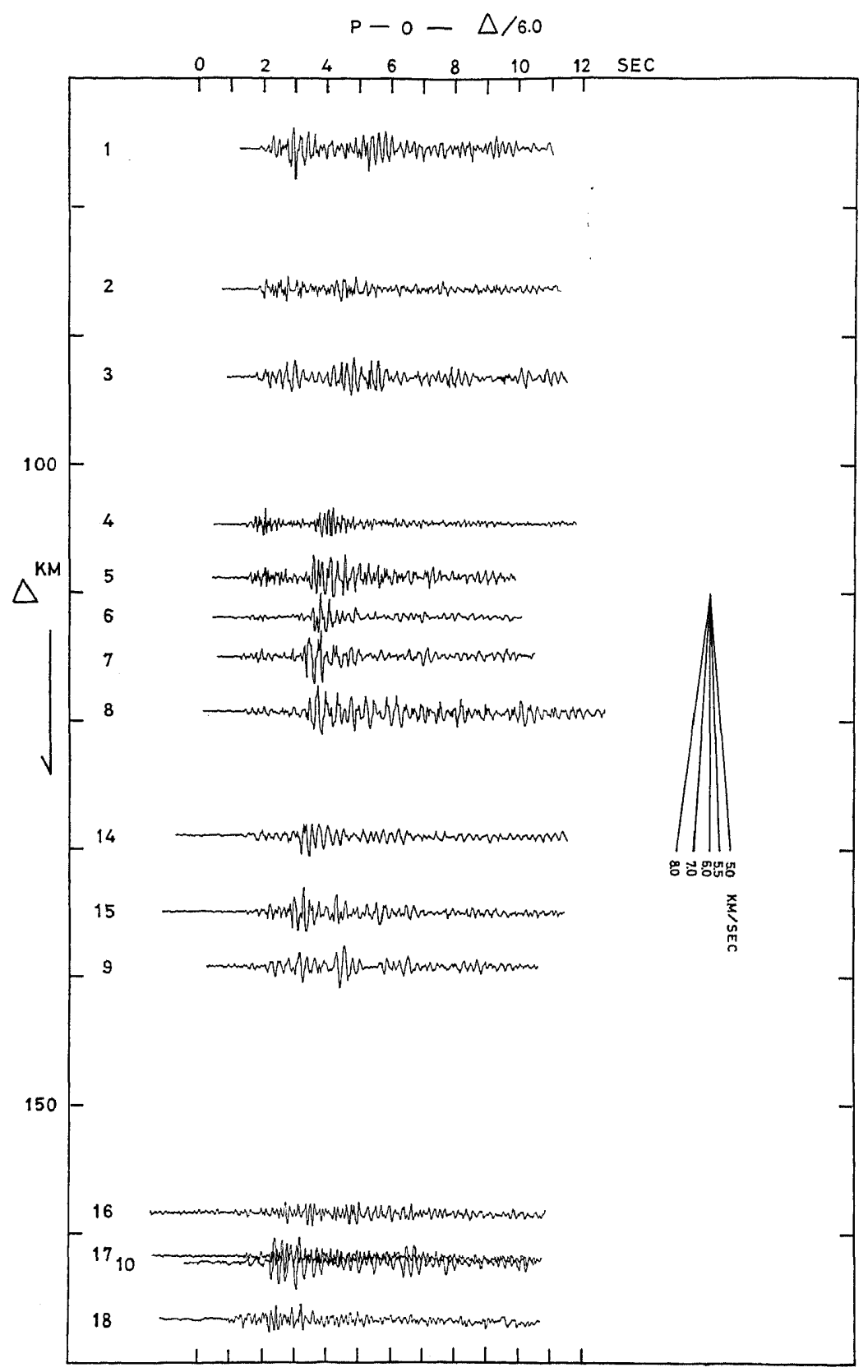

Fig. 2(a). Record section obtained through our observation in the sixth, seventh and eighth Yumenoshima explosions. Numerals in each seismograms give the station number. 


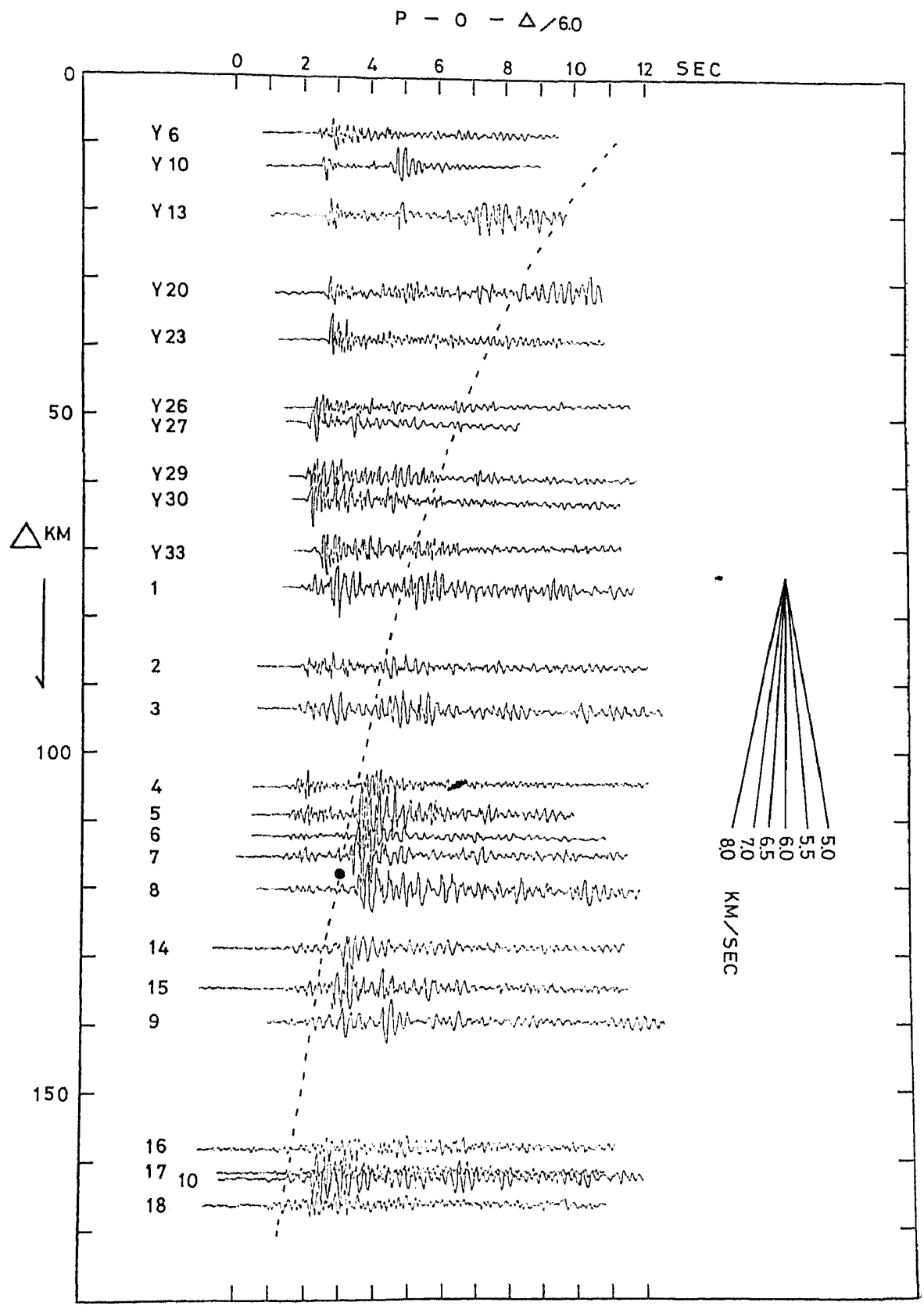

Fig. 2(b). Record section including seismograms in the forth and fifth Yumenoshima explosions. The station number is given to each seismogram. The theoretical travel time curve of reflected wave from the Moho in Fig. 7 is shown by a dotted line. A solid circle shows the critical point. 
A record section obtained by us in the sixth, seventh and eighth Yumenoshima experiments is shown in Fig. 2(a). Seismograms at distances less than $75 \mathrm{~km}$ were obtained from the forth and fifth Yumenoshima experiments by RGBS (stations $Y 6$ through Y33). A record section including these seismograms is shown in Fig. 2(b). Seismograms at stations No. 4 through No. 6, No. 7 through No. 10 and No. 14 through No. 18 were obtained in the sixth, seventh and eighth Yumenoshima experiments respectively. A distinct late arrival is easily identified in each seismogram of No. 1 through No. 18 in Fig. 2. This phase arrives about $2.0 \mathrm{sec}$ later than the first arrival. In addition to this phase, another phase is present about $0.3 \mathrm{sec}$ later than the first arrival in seismograms at stations No. 1 through No. 7. The first and second late arrivals of about $0.3 \mathrm{sec}$ and $2.0 \mathrm{sec}$ after the first arrival are called in this paper Later 1 and Later 2, respectively. The reduced travel time graph for the first and these later arrivals is shown in Fig. 3 and the travel time data are given in Table 2.

A model of the underground structure in the Yumenoshima western profile has been derived by SHIma et al. (1978) as shown in Fig. 4. There are low velocity superficial layers over the basement with a velocity of $5.3 \mathrm{~km} / \mathrm{s}$. From the travel time analysis, it is known that these low velocity layers exist up to a distance about $50 \mathrm{~km}$ from the Yumenoshima shot point.

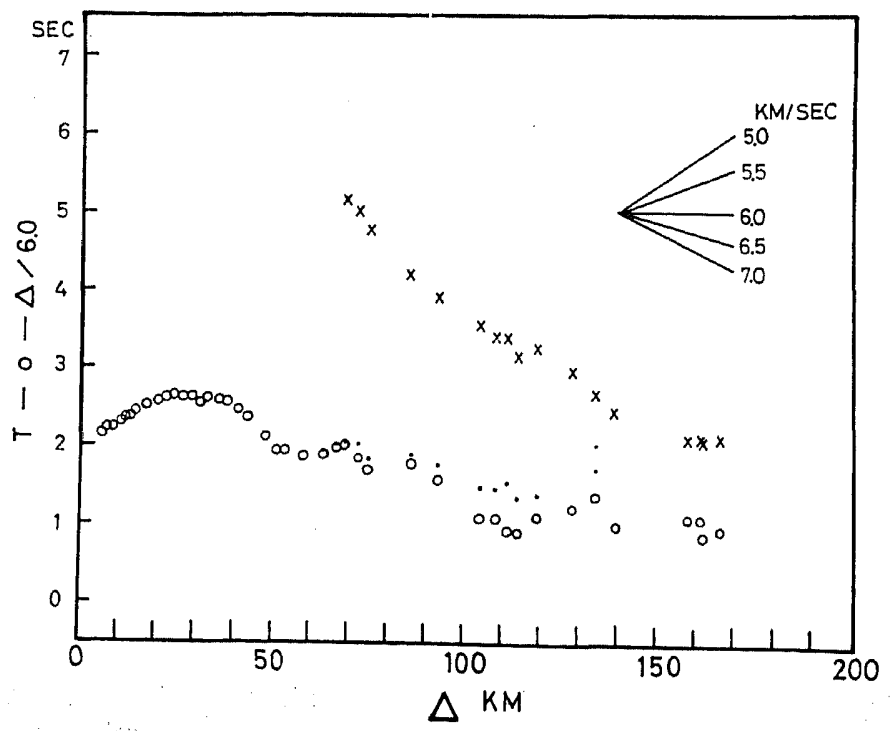

Fig. 3. Reduced travel times of the first arrival and two late arrivals. Open circle, the first arrival; solid circle, the first later arrival, Later 1; cross mark, the second later arrival, Later 2. 
Table 2. The travel times of the first arrivals and two later arrivals.

\begin{tabular}{|c|c|c|c|c|c|c|}
\hline $\begin{array}{l}\text { Station } \\
\text { number }\end{array}$ & $\begin{array}{l}\text { Observation } \\
\text { point }\end{array}$ & $\begin{array}{c}\text { Distance } \\
\Delta(\mathrm{km})\end{array}$ & $\begin{array}{l}P \sim O^{*} \\
(\mathrm{sec})\end{array}$ & $\begin{array}{c}P-O-\Delta / 6 \\
(\mathrm{sec})\end{array}$ & $\begin{array}{l}\text { Later } 1-O^{*} \\
\quad(\mathrm{sec})\end{array}$ & $\begin{array}{c}\text { Later } 2-O^{*} \\
\quad(\mathrm{sec})\end{array}$ \\
\hline YMS & Yumenoshima & 0.00 & & & & \\
\hline$Y 29$ & Sokozawa & 58.89 & 11.69 & 1.88 & 11.70 & \\
\hline Y30 & Hashizume & 63.10 & 12.37 & 1.85 & 12.43 & \\
\hline Y 32 & Kokura & 67.15 & 13.11 & 1.92 & 13.15 & \\
\hline Y33 & Kawakubohigashi & 69.29 & 13.56 & 2.01 & 13.60 & 16.70 \\
\hline Y 34 & Okuyama & 72.86 & 13.97 & 1.83 & 14.17 & 17.15 \\
\hline 1 & Asakawa & 75.34 & 14.25 & 1.69 & 14.42 & 17.32 \\
\hline 2 & Kuwanishi & 86.27 & 16.14 & 1.76 & 16.27 & 18.59 \\
\hline 3 & Tenmokuzan B & 93.12 & 17.07 & 1.55 & 17.29 & 19.43 \\
\hline 4 & Mizuguchi & 104.53 & 18.52 & 1.10 & 18.91 & 20.97 \\
\hline 5 & Hotokezawa & 108.73 & 19.21 & 1.09 & 19.59 & 21.53 \\
\hline 6 & Toichi & 111.93 & 19.57 & 0.92 & 20.21 & 22.03 \\
\hline 7 & Touiwa & 114.99 & 20.07 & 0.91 & 20.49 & 22.33 \\
\hline 8 & Urushido & 119.18 & 20.97 & 1.11 & 21.21 & 23.13 \\
\hline 9 & Otakezawa & 139.01 & 24.17 & 1.00 & 24.32 & 25.63 \\
\hline 10 & Oshika & 162.22 & 27.91 & 0.87 & 27.99 & 29.13 \\
\hline 14 & Amarizawa & 128.97 & 22.72 & 1.23 & & 24.47 \\
\hline 15 & Gozaishi & 134.84 & 23.86 & 1.39 & $\left(\begin{array}{l}24.18 \\
24.51\end{array}\right)$ & 25.17 \\
\hline 16 & Komagane 1 & 158.35 & 27.51 & 1.12 & & 28.49 \\
\hline 17 & Komagane 2 & 161.76 & 28.08 & 1.12 & & 29.08 \\
\hline 18 & Komagane 3 & 166.57 & 28.74 & 0.98 & & 29.89 \\
\hline INB & Inabu & 0.00 & & & & \\
\hline 10 & Oshika & 61.76 & 10.68 & 0.39 & & \\
\hline 11 & Yashagin & 87.39 & 15.17 & 0.60 & & \\
\hline 5 & Hotokezawa & 115.46 & 19.42 & 0.17 & & \\
\hline 12 & Ichinose & 137.43 & 23.02 & 0.12 & & \\
\hline 13 & Shiroku & 155.57 & 26.20 & 0.27 & & . \\
\hline
\end{tabular}

* $P$, the first arrival; $O$, shot time; Later 1 , the first later arrival; Later 2, the second later arrival.

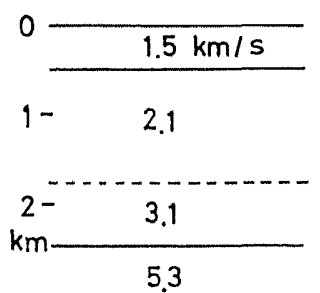

Fig. 4. The underground structure in the Yumenoshima western profile (after Shima et al., 1978).

In order to analyse the travel time data, it is necessary to remove the effect of these low velocity layers on travel times for stations within a distance less than about $50 \mathrm{~km}$. Therefore, travel time data for all stations are corrected by replacing low velocity layers with the basement. 


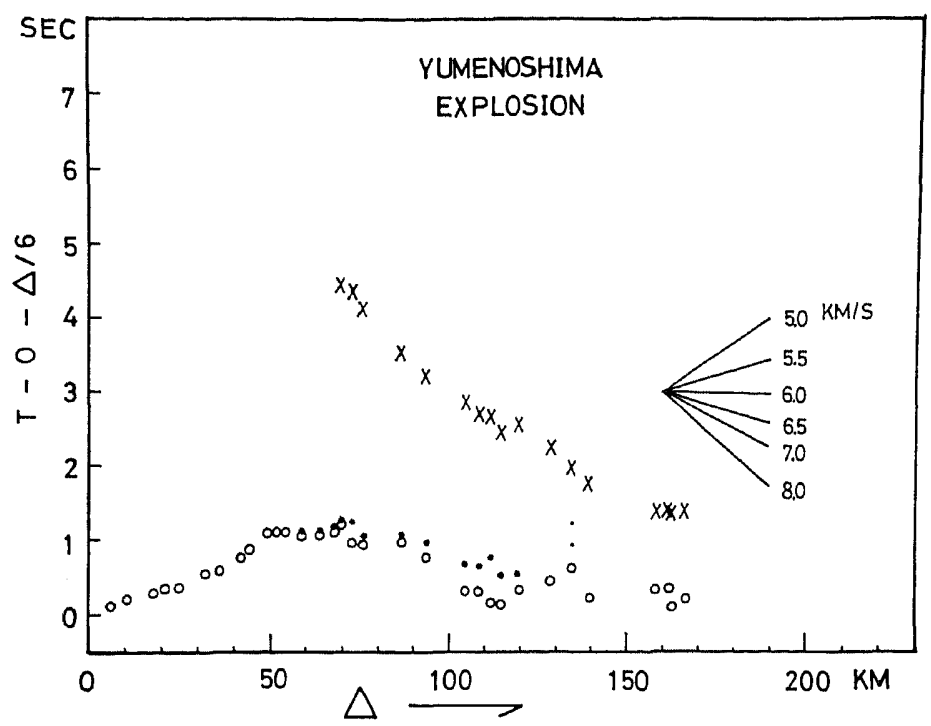

Fig. 5. Reduced travel time plot after the correction of surface layers was applied. The marks of plot are the same with those in Fig. 3.

Table 3. Corrected travel times of the first arrivals and two later arrivals.

\begin{tabular}{|c|c|c|c|c|c|}
\hline $\begin{array}{l}\text { Station } \\
\text { number }\end{array}$ & $\begin{array}{l}\text { Observation } \\
\text { point }\end{array}$ & $\begin{array}{l}\text { Distance } \\
\Delta(\mathrm{km})\end{array}$ & $\begin{array}{c}\left(P^{\prime *} *_{-}-O-\Delta / 6\right) \\
(\mathrm{sec})\end{array}$ & $\begin{array}{c}\left(\text { Later }{ }^{1 *}{ }_{-} O-\right. \\
(\mathrm{sec})\end{array}$ & $\begin{array}{c}\left(\text { Later } 2^{\prime *-O-A} * 6\right) \\
(\mathrm{sec})\end{array}$ \\
\hline YMS & Yumenoshima & 0.00 & & & \\
\hline Y 29 & Sokozawa & 58.89 & 1.07 & 1.11 & \\
\hline Y30 & Hashizume & 63.10 & 1.05 & 1.13 & \\
\hline $\mathrm{Y} 32$ & Kokura & 67.15 & 1.11 & 1.18 & \\
\hline Y33 & Kawakubohigashi & 69.29 & 1.21 & 1.27 & 4.48 \\
\hline Y34 & Okuyama & 72.86 & 1.02 & 1.24 & 4.35 \\
\hline 1 & Asakawa & 75.34 & 0.93 & 1.07 & 4.10 \\
\hline 2 & Kuwakubo & 86.27 & 1.00 & 1.10 & 3.54 \\
\hline 3 & Tenmokuzan B & 93.12 & 0.78 & 0.97 & 3.24 \\
\hline 4 & Mizuguchi & 104.53 & 0.33 & 0.69 & 2.87 \\
\hline 5 & Hotokezawa & 108.73 & 0.33 & 0.67 & 2.72 \\
\hline 6 & Toichi & 111.93 & 0.16 & 0.76 & 2.69 \\
\hline 7 & Touiwa & 114.99 & 0.14 & 0.53 & 2.47 \\
\hline 8 & Urushido & 119.18 & 0.34 & 0.55 & 2.58 \\
\hline 9 & Otakezawa & 139.01 & 0.24 & & 1.75 \\
\hline 10 & Oshika & 162.22 & 0.11 & & 1.38 \\
\hline 14 & Amarizawa & 128.97 & 0.62 & & 2.27 \\
\hline 15 & Gozaishi & 134.84 & 0.47 & $\left(\begin{array}{l}0.90 \\
1.23\end{array}\right)$ & 1.99 \\
\hline 16 & Komagane 1 & 158.35 & 0.36 & & 1.39 \\
\hline 17 & Komagane 2 & 161.76 & 0.36 & & 1.40 \\
\hline 18 & Komagane 3 & 166.57 & 0.21 & & 1.41 \\
\hline
\end{tabular}

* $\quad P^{\prime}$, corrected $P$; Later $1^{\prime}$, corrected Later 1; Later 2', corrected Later 2. 
Travel time data thus corrected are shown in Fig. 5 and listed in Table 3.

\section{Features of Clear Later Arrivals}

In general, it is not easy to clarify traveling paths of later arrivals uniquely. To derive a precise model of crustal structure, the correlation of later arrivals from one station to another is most important. In the present case, the later arrivals observed are quite pronounced and the correlation of these arrivals from one station to another is fairly good as seen in Fig. 2. Therefore, the following analyses were made mainly to clarify features of Later 2.

\subsection{Travel time analysis}

In general, the travel time of a reflected wave should satisfy the following formula:

$$
T^{2}=\left(\Delta^{2}+4 H^{2}\right) / V^{2}
$$

where $T$, travel time; $\Delta$, distance from a shot point; $H$, depth of the reflector; $V$, average velocity from the surface to the reflector.

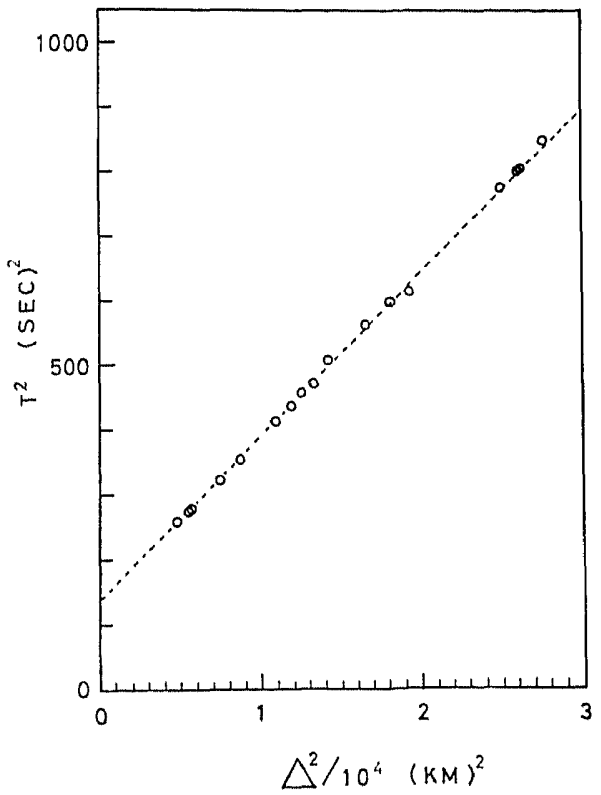

Fig. 6. The graph of $T^{2}$ vs. $\Delta^{2}$ based on the travel time data of Later 2. $T$, the corrected travel time; $\Delta$, the distance from the Yumenoshima shot point. 
This formula shows that a linear relation exists between $T^{2}$ and $\Delta^{2}$. The $T^{2}$ vs $\Delta^{2}$ graph based on the data of Later 2 is shown in Fig. 6 . Since the data of Later 2 fit on a line as seen in Fig. 6, Later 2 has the feature of a reflected wave. It is estimated by using the above fomula that the depth to the reflector is about $37 \mathrm{~km}$ and the average velocity above the reflector is about $6.3 \mathrm{~km} / \mathrm{s}$.

A crustal model is next constructed as shown in Fig. 7 on the basis of the preceding analysis as well as the existing information on the crustal structure. Since the velocity beneath the Moho can not be derived from the present data, it is assumed from the results in the area concerned. The theoretical travel time curve of the reflected wave from the deepest boundary in this model is shown in Fig. 8 with observed data of Later 2.

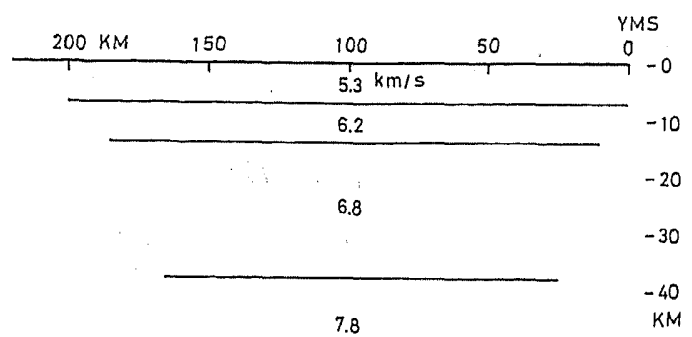

Fig. 7. The crustal model for the travel time analysis.

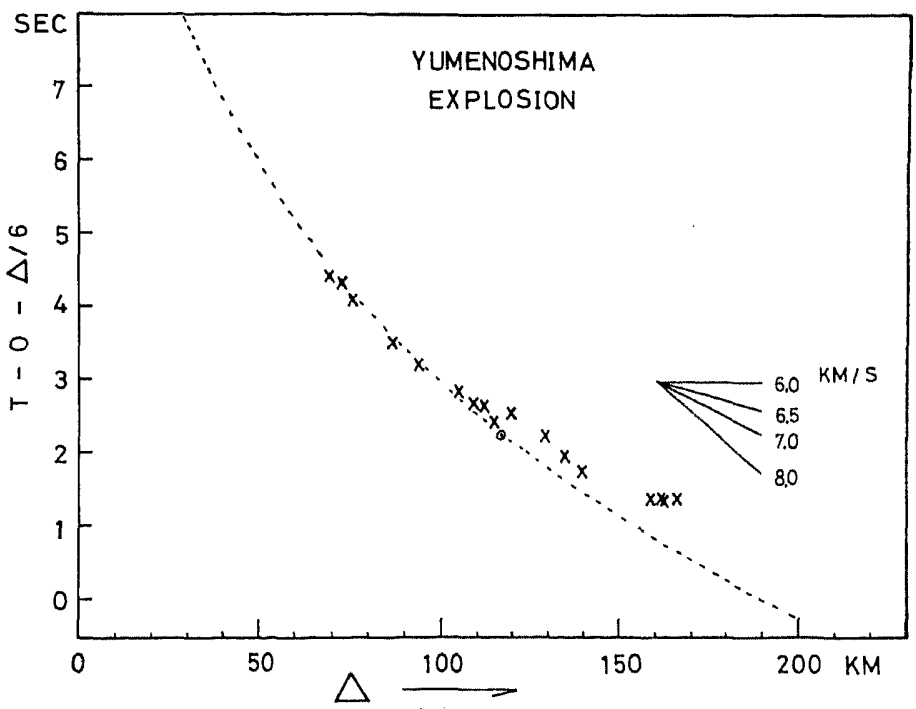

Fig. 8. The theoretical travel time curve of reflected wave from the deepest boundary based on the model in .Fig. 7 and corrected travel times from observed.data (cross marks). The critical point is shown by a double circle. 
This theoretical curve is also shown by a dotted line in the record section of Fig. 2(b). In this theoretical curve the effect of low velocity layers in the Yumenoshima western profile is removed. Since travel time data of Later 2 fit on the theoretical curve, this late arrival, Later 2, is identified with the reflected wave from the Moho.

\subsection{Amplitude analysis}

The theoretical amplitude of seismic waves with special reference to crustal structure has been studied by many investigators. The theoretical amplitude of seismic waves derived from the structure as shown in Fig. 9(a) is presented in Fig. 9(b) on the basis of investigations by CERVENY and RAvindRA (1971). According to the theoretical curves in Fig. 9(b), the amplitude of the reflected wave from the deepest boundary has a minimum between a shot point and the critical distance. After reaching a maximum, it shows a slow decrease over the critical distance. The observed maximum amplitude of Later 1 and Later 2 is plotted in Fig. 10. From the study of travel time data of Later 1 , this wave is identified with the refracted wave from the upper boundary of the layer with a velocity or $6.2 \mathrm{~km} / \mathrm{s}$. The maximum amplitude of Later 1 decreases rapidly as the distance increases and this tendency is similar to that of the theoretical curve of the refracted wave as shown in Fig. 9(b). The maximum amplitude of Later 2 increases slowly up to a distance of about $110 \mathrm{~km}$ and decreases beyond this distance.

The amplitude of seismic waves is influenced by the shallow structure near the station. To remove this influence, the ratio of the observed amplitude of Later 2 to that of Later 1, Later 2/Later 1, is derived and shown

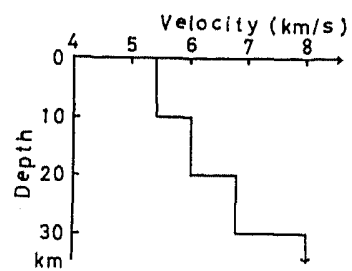

(a)

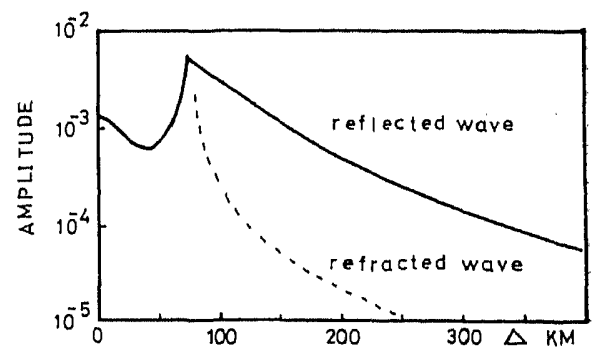

(b)

Fig. 9. (a) The model for theoretical calculation of amplitude. (b) The theoretical amplitude curve of the seismic waves (after CERVENY and RAVINDRA, 1971). The amplitude curve for the reflected wave from the deepest boundary of the model is given by a solid curve and that for the refracted wave from the same boundary, by a dashed curve. 


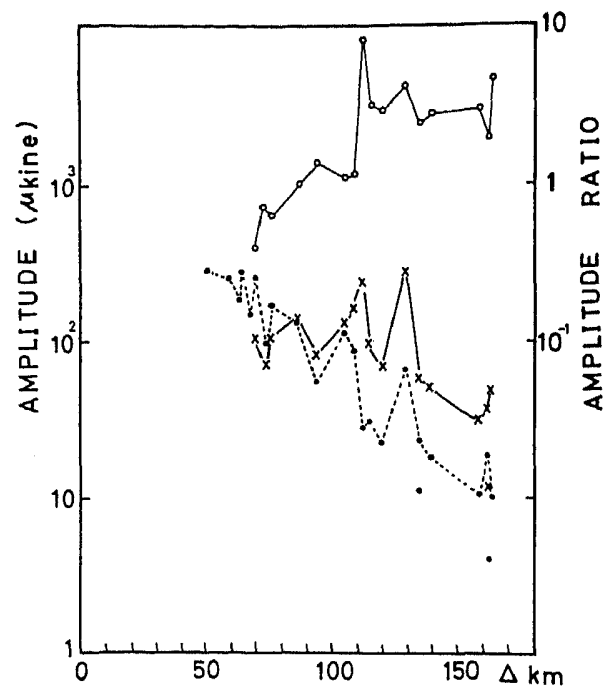

Fig. 10. The observed maximum amplitude of Later 1, Later 2, and the amplitude ratio, Later 2/Later 1. Solid circle, maximum amplitude of Later 1 ; cross mark, maximum amplitude of Later 2; open circle, amplitude ratio, Later 2/Later 1.

in Fig. 10. This ratio reaches the maximum value near $110 \mathrm{~km}$. This feature can be explained from the theoretical amplitude curve.

These results of the amplitude analysis also support the conclusion that Later 2 is a reflected wave from the Moho.

\section{Crustal Structure in the Western Kanto District}

Now the theoretical travel time derived from the model in Fig. 7 is compared with the corrected travel time as shown in Fig. 11. Each branch of theoretical travel time in Fig. 11 is explained in the following:

$T$ 1: The travel time of direct wave in the surface layer with a velocity of $5.3 \mathrm{~km} / \mathrm{s}$

T2: The travel time of refracted wave from the second layer with a velocity of $6.2 \mathrm{~km} / \mathrm{s}$

T3: The travel time of reflected wave from the upper boundary of the layer with a velocity of $6.8 \mathrm{~km} / \mathrm{s}$

T4: The travel time of refracted wave from the third layer with a velocity of $6.8 \mathrm{~km} / \mathrm{s}$

T5: The travel time of reflected wave from the Moho

T6: The travel time of refracted wave from the Moho, that is, $P_{n}$ wave. 


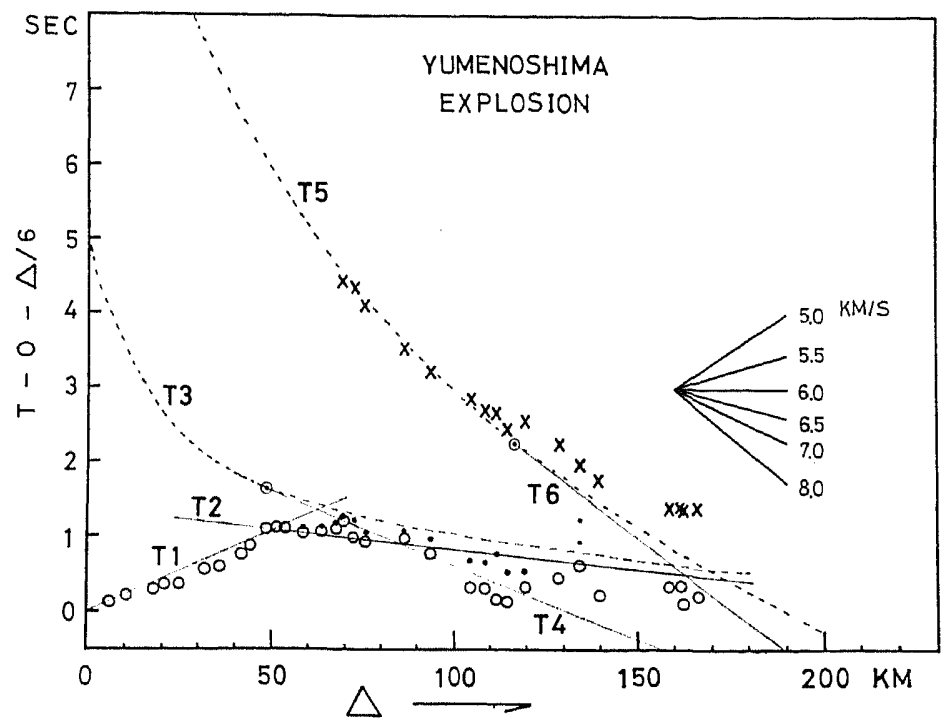

Fig. 11. The theoretical travel time curve based on the model in Fig. 7 and observed travel time data. Each travel time plot is the same with that in Fig. 5. The explanation of $T 1$ through $T 6$ is given in the text. The critical point is shown by a double circle.

As seen in Fig. 11, from 100 to $120 \mathrm{~km}$ the observed travel times of the first arrival are shorter than the theoretical ones, but beyond $120 \mathrm{~km}$ they are longer than the theoretical ones. If these delays are considered to be caused by the local superficial layers, it is necessary to modify the model of Fig. 7.

To revise the model of Fig. 7, the data of the Inabu quarry blast are useful. The record section of the Inabu quarry blast is shown in Fig. 12. The travel time $T 2$ presented in Fig. 11 is compared with observed travel time data of the Inabu quarry blast as shown in Fig. 13. The underground structure near Inabu has been derived by IKAMI et al. (1977). According to their model, the thickness of the first layer with a velocity of $5.3 \mathrm{~km} / \mathrm{s}$ is about $1.5 \mathrm{~km}$. Since this thickness is $7.0 \mathrm{~km}$ in our model, the theoretical travel time $T 2$ should be corrected as shown in Fig. 13 by a dotted line. This corrected travel time $T 2$ fits the observed data fairly well. Therefore, these first arrivals are identified with the wave refracted from the second layer with a velocity of $6.2 \mathrm{~km} / \mathrm{s}$ in Fig. 7 .

The final model which gives a reasonable agreement between observed travel times and theoretical ones is shown in Fig. 14. This model has an offset in the upper boundary of the second layer by about 4 to $8 \mathrm{~km}$ around the distance $110 \mathrm{~km}$ from the Yumenoshima shot point, in addition 


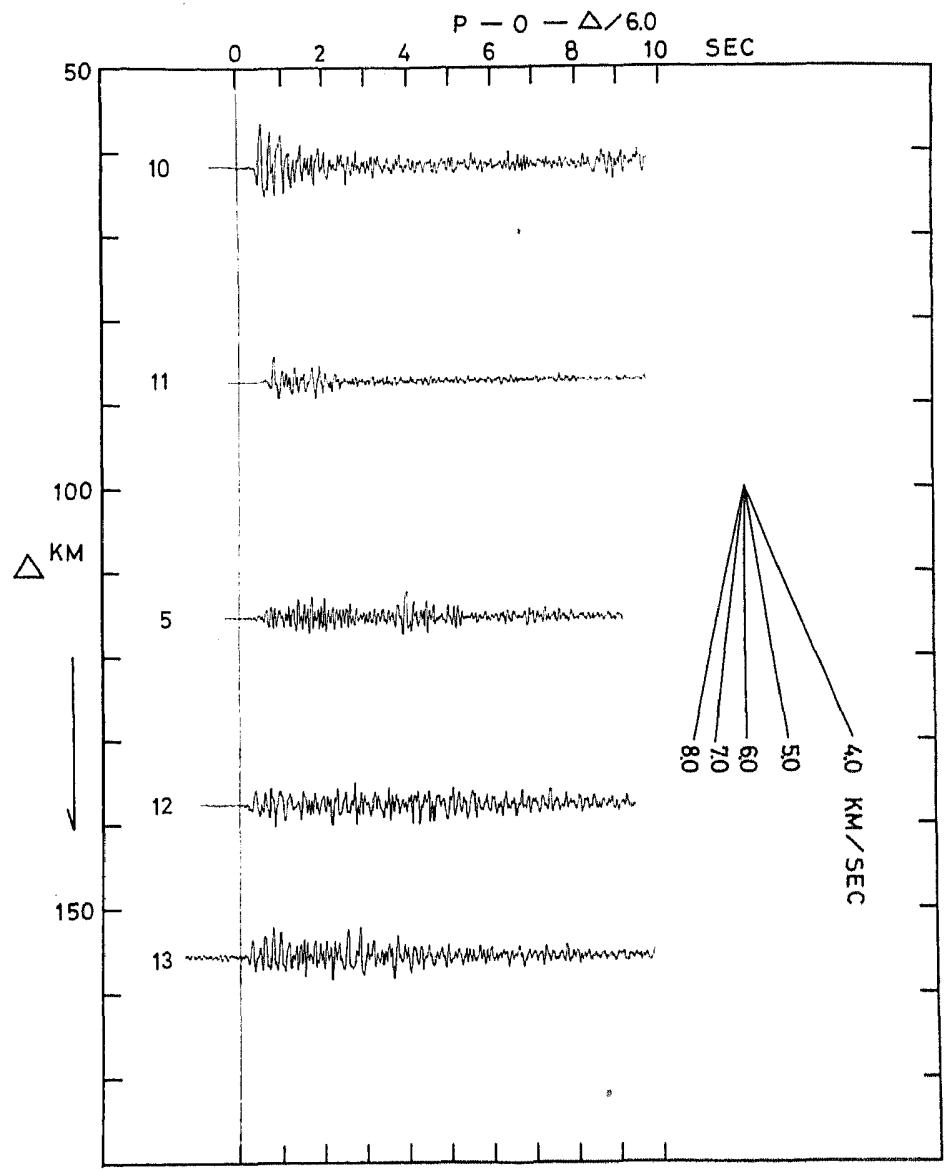

Fig. 12. Record section of the Inabu quarry blast. The station number is given in each seismogram.

to a dipping tendency in this boundary from the west to the east. The offset is derived from the delay of travel times (cf. Fig 11: T4, T5). In other words, the first layer becomes thick in the distance range 110-150 $\mathrm{km}$. It is interesting to note that the area over the above offset is near the Fossa Magna. One of the features of this model is that the Moho dips toward the Fossa Magna and the crustal thickness in the western Kanto district is about 38 to $45 \mathrm{~km}$.

In 1961, 1962 and 1963, explosion seismic observations were carried out across Honshu along the $139^{\circ} \mathrm{E}$ longitudinal line (HotTA et al., 1964). This line is close to the Fossa Magna in the southern part. In 1964, the observation of aftershocks of the Niigata earthquake was carried out along the same line (ASADA and SHIMA, 1968). The results of these observations show that the apparent velocities derived from the first arrivals are about 


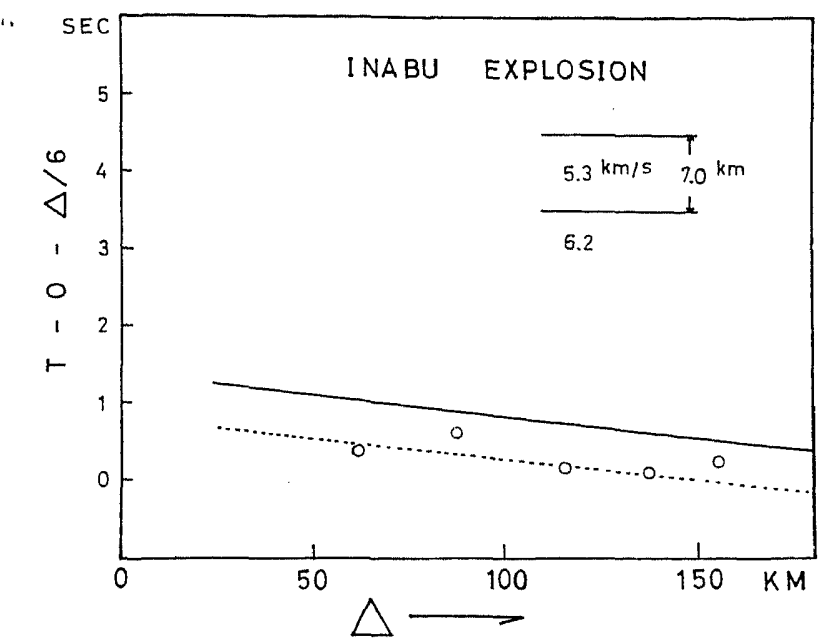

Fig. 13. Reduced travel time plot of the Inabu quarry blast. Solid line, travel time $T 3$ shown in Fig. 11; dotted line, corrected $T 3$.

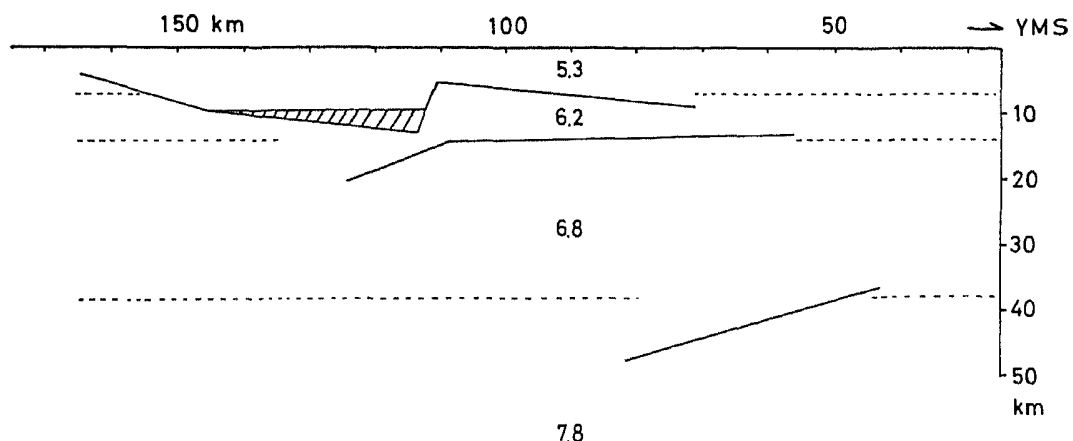

Fig. 14. The crustal structure in the western Kanto district. A numeral in each layer gives $\mathrm{P}$ wave velocity in $\mathrm{km} / \mathrm{s}$. The shaded part shows different solutions derived from the travel time analysis. The dotted line shows the model in Fig. 7 for comparison.

6.6 to $6.8 \mathrm{~km} / \mathrm{s}$, although observation was made at distances sufficiently large to record the $P n$ wave. In other words, in crust along this line a thick intermediate layer with a velocity of 6.6 to $6.8 \mathrm{~km} / \mathrm{s}$ is present. These results agree with the present crustal model in the western Kanto district, since the crustal model in Fig. 14 becomes thicker as the Fossa Magna is approached.

\section{Conclusions}

Seismic waves generated by the sixth to the eighth Yumenoshima 
explosions were observed in the distance range of 70-170 km westward to record waves reffected from the deep boundaries. A distinct late arrival of about $2.0 \mathrm{sec}$ after the first arrival was recorded at distances larger than $70 \mathrm{~km}$. From the analyses of travel times and amplitudes of this wave, it is concluded that this pronounced wave is that reflected from the Moho. Such a clear reflection from the Moho has so far never been recorded in Japan. Records of such a clear reflection implies the existence of a boundary similar to that beneath a typical continental region even in complicated areas like Japan.

From the travel time data of the late arrival mentioned above as well as other waves, the crustal structure in the western Kanto district was derived. The crust consists of layers with velocities of 5.3,6.2 and $6.8 \mathrm{~km} / \mathrm{s}$, the average thicknesses of which are $7.0,7.0$ and $24 \mathrm{~km}$, respectively. The crust becomes thicker to the west and its thickness is about 38 to $45 \mathrm{~km}$. These features of the crustal structure are compatible with previous results around the western Kanto district.

We wish to express our hearty gratitude to participants in observation of seismic waves from Yumenoshima explosions for offering observed materials.

\section{REFERENCES}

AsAda, T. and E. Shima, Observation of Niigata aftershocks at mobile stations, in General Report on the Niigata Earthquake of 1964, pp. 87-95, Tokyo Electric Engineering College Press, Tokyo, 1968.

Cerveny, V.F. and R. Ravindra, Head waves in multilayered media, in Theory of Seismic Head Waves, pp. 188-224, University of Tronto Press, Tronto, 1971.

Hotra, H., S. Murauchi, T. Usami, E. Shima, Y. Motoya, and T. Asanuma, Crustal structure in central Japan along longitudinal line $139^{\circ} \mathrm{E}$ as derived from explosionseismic observations. Part 2. Crustal structure, Bull. Earthq. Res. Inst., 42, 533-.541, 1964.

IKami, A., I. Yamada, H. MURakami, N. HurukaWA, and F. Taknuchi, Crustal structure in central Japan as derived from the Inabu quarry blast observations, Bull. Disast. Prev. Res. Inst., 27, 23-46, 1977.

Shima, E., M. Yanagisawa, K. Kudow, T. Yoshir, K. Sio, and K. Kuroha, On the base rock of Tokyo III. Observations of seismic waves generated from the 4th and 5th Yumenoshima explosions, Bull. Earthq. Res. Inst., 53, 305-318, 1978 (in Japanese).

Yoshin, T., Y. Sasaki, T. Tada, H. Okada, S. Asano, I. Muramatu, M. Hashizume, and T. MORIYA, The third Kurayoshi explosion and the crustal structure in western part of Japan, J. Phys. Earth, 22, 109-121, 1973. 